СТАСЮК О. І., д.т.н., професор,

ГОНЧАРОВА Л. Л., к.т.н., доцент (Державний економіко-технологічний університет транспорту)

\title{
Математичні моделі і методи організації інтелектуальних мереж постачання електроенергії на тягу залізничному транспорту
}

Проведений аналіз комплексної проблеми оптимізації режимів електропостачання на тягу, запропоновано топологію графа, щзо адекватно відображає архітектуру типової локальної обчислювальної мережі тягової підстанції, $і$ математичну модель для визначення сукупності ймовірностей стану відповідних вузлів, застосовано математичний апарат диференційних перетворень Пухова як основи створення інтелектуальних мереж постачання електроенергії і визначення їх характеристик.

Ключові слова: інтелектуальні електричні мережі, математичні моделі, SMART Grid, диференційні перетворення, граф, локальна мережа, тягова підстанція.

\begin{abstract}
Постановка проблеми
Проблема створення сучасних комп'ютерних i інформаційних технологій для організації, в реальному часі, оперативного управління процесами електропостачання залізницям та формування на їх базі енергозберігаючих технологій електроспоживання i покращення рівня безпеки руху при мінімальних інвестиціях можливо завдяки створенню математичних моделей і методів комп'ютеризації і інтелектуалізації швидкоплинних технологічних процесів електропостачання на тягу i формування на їх базі інтелектуальних мереж залізничного транспорту [1 3]. Пошук нових шляхів і підходів для розв'язання комплексу задач, пов'язаних 3 розробкою математичних моделей інтелектуалізації технологічних процесів електропостачання в умовах функціонування ринку електроенергії, стимулював проведення наукових досліджень в сфері створення нових концептуальних підходів, принципів інтелектуалізації режимів оптимального функціонування тягових систем, мінімізації електроспоживання комерційної вартості електроенергії та покращення безпеки руху залізничного транспорту. Досвід експлуатації i результати впровадження сучасних комп'ютерних засобів i інформаційних та мережевих технологій оперативного керування електропостачанням залізницям показав широкий спектр можливостей в сферах оптимізації режимів електричних мереж, енергозбереження в процесі електроспоживання, покращення надійності функціонування і відкрив новий етап комп'ютерної інтелектуалізації швидкоплинних технологічних процедур електропостачання, а також розробки на їх базі
\end{abstract}

(C) О.І. Стасюк, Л.Л. Гончарова, 2015 перспективних IT- технологій енергозбереження та безпеки руху [7-9]. Необхідно відмітити, що на економічність режимів, збільшення собівартості споживання електроенергї та надійність функціонування енергосистеми також додатково негативно впливають фізичне та моральне старіння силового електрообладнання тягових підстанцій i мереж електропостачання, які находяться в експлуатації. Цей факт також підкреслює необхідність рішення проблеми створення математичних моделей комп'ютеризації швидкоплинних технологічних процесів електроспоживання і на їх основі організації інтелектуальних тягових мереж електропостачання залізничному транспорту.

\section{Аналіз останніх досліджень і публікацій}

На основі аналізу останніх публікацій і комплексу проведених досліджень можна заключити, що загальновизнаним у світі став напрямок, пов'язаний з оптимізацією швидкоплинних технологічних процесів постачання електроенергії на тягу шляхом застосуванням сучасних комп'ютерних і мережевих технологій для проведення в реальному часі оперативного управління електропостачанням $[1,3,8]$. Стало очевидним, що створення нових математичних моделей, методів, комп'ютерно - орієнтованих алгоритмів для інтелектуалізації тягових електричних мереж залізниць передбачає проведення суттєвих наукових досліджень i пошуку нових шляхів. Домінуючим у світі, як показано в роботах $[1-4,9]$, став напрямок, пов'язаний 3 інтелектуалізацією електричних мереж, що базується на SMART Grid технології. Перспективність SMART Grid - технології обумовлюється створенням нової моделі інтелектуалізації тягових електричних мереж, що передбачає комплекс сучасних наукових і інженерних рішень в сфері комп'ютерних, мережевих і 
І Н Ф О Р М А ЦІ ЙН О - КЕ Р У ЮЧ І С И С Т Е М И Н А 3 А Л І З Н ИЧ Н О М У Т Р А Н С П О Р Т І

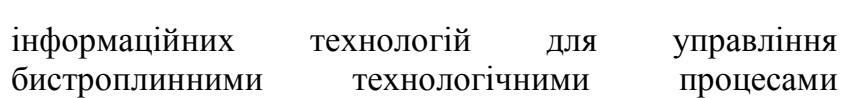
постачання електроенергії. Модель інтелектуалізації організована на основі ряду принципів самовідновлення, саморегуляції, єдиного інформаційного простору i означає, по суті, самоконтролюючу, аналізуючу і звітуючу технологію, орієнтовану для управління бистроплинними технологічними процедурами електроспоживання на тягу. Оперативне керування при цьому реалізується в реальному часі за допомогою інтегрованої розподіленої інформаційно-керуючої мережі, архітектура якої адекватно відображає топологію залізничної системи електропостачання. Використання інтелектуальних тягових мереж електропостачання відкриває також нову якість суттєвого розширення ринкових можливостей шляхом надання широкого спектру взаємних послуг між суб'єктами ринку електроенергії і інфраструктурою електричної системи як окремої залізниці, так і Укрзалізниці в цілому [2, 7].

\section{Відокремлення нерозв'язаних раніше частин загальної проблеми}

Підсумовуючи результати проведеного аналізу сучасних публікацій i базуючись на результатах проведених авторами досліджень, виділимо нерозв'язані раніше частини загальної проблеми інноваційного перетворення тягових електричних мереж залізниць. Аналіз еволюції розвитку тягових електричних мереж і комп'ютерних систем управління ними дозволяє зробити висновок, що досягти високий рівень інтелектуалізації мереж електропостачання можливо завдяки проведенню глибокої взаємоінтеграції електричних мереж залізниць і комп'ютерних інформаційно-керуючих систем.

Для створення інтелектуальної мережі електропостачання залізницям необхідно, в першу чергу, організувати єдину інформаційну модель як основу повномасштабного інформаційного забезпечення, створення математичних моделей i методів оптимізації електроспоживання, інтеграції електромережевої інфраструктури та інформаційної комп'ютерної архітектури, організації всережимної системи керування та розширення ринкових можливостей, i, на iï базі, формування процедур культури споживання та стимулювання економічного розвитку $[2,3,9]$. Синтезована таким чином інтелектуальна електроенергетична система постачання енергії на тягу залізницям є якісно новою сукупністю взаємно - інтегрованих електричних тягових мереж і розподілених комп'ютерних засобів та технологій керування, генеруючих потужностей, засобів захисту, об'єднаних на основі сучасних принципів єдиного інформаційного простору, саморегулювання, самовідновлення, принципу підтримки єдиної моделі первинних даних i синхронної інформаційної взаємодії. Такий підхід створення інтелектуальних тягових мереж відкриває можливість накопичувати нові «знання» функціонування системи електропостачання, що дозволить різко підвищити ефективність тягової мережі, забезпечити інтелектуальний облік електроенергії по комерційним диференційованим тарифам i реалізувати інтегральну тарифікацію та мінімізувати загальносистемні витрати. Крім того, 3'являються нова можливість розширити спектр послуг в умовах ринку електроенергії, оптимізувати функціонування тягових мереж шляхом організації оперативного i стратегічного керування на основі сучасних методів інтелектуалізації та ситуаційного моделювання, організувати технічне обслуговування, включаючи i ремонтні роботи за станом, а також забезпечити основу створення енергозберігаючих ITтехнологій та інформаційних технологій, орієнтованих на покращення рівня безпеки руху [3].

\section{Мета роботи}

На основі теорії диференційних перетворень i теорії графів розробка математичних моделей функціонування інформаційних потоків тягових підстанцій та методів комп'ютеризації швидкоплинних технологічних процесів електроспоживання i, на їх базі, способів організації інтелектуальних електричних мереж залізниць, в основу яких закладені сучасні принципи єдиного інформаційного простору, синхронної інформаційної взаємодії, єдиної моделі первинних даних, відкриває можливість оптимізувати електропостачання, покращити якість i надійність електроспоживання, зменшити загальносистемні витрати електроенергії та сформувати сучасні ITтехнології енергозбереження i безпеки руху залізничного транспорту.

\section{Основний матеріал дослідження}

Вирішення проблеми оперативно-диспетчерського, технологічного i організаційного управління процесами електропостачанням залізниць пов'язано 3 рішенням широкого спектру задач інженерного та технічно-експлуатаційного характеру, а також комплексу економічних питань, пов'язаних з оптовими закупками електроенергії на ринку, споживанням іiі і реалізації на комерційних умовах районним i нетяговим споживачам. Комп'ютеризація технологічних процесів електропостачання 3 інженерної точки зору і інтелектуалізація сукупності процедур оперативного управління потребує, в першу чергу, повноти i навіть деякої надлишковості інформації, що, в свою чергу, пов’ язано з необхідністю організації, в реальному часі, безперервного моніторингу режимів функціонування не тільки мереж електропостачання, a i силового електричного обладнання тягових підстанцій системи постачання 
енергії на тягу. В основи ідеології інтелектуальних тягових мереж буде використана технологія комплексної інфраструктури реєстрації і формування первинної інформації з загальносистемних позицій у вигляді єдиного інформаційного середовища, що відповідає умовам синхронності і єдності вимірювання. Подібна організація первинної інформації відкриває можливість функціонування в реальному часі перспективних і ретроспективних баз даних як основи створення сучасних IT- технології енергозбереження i безпеки руху залізничного транспорту, організацію мереж інтерфейсів користувачів, а також реалізувати уніфікацію документообігу, що є дуже важливим. До ключових технологічних інструментів інтелектуальних тягових мереж можна включити інтелектуальне силове обладнання та силову електроніку 3 вбудованими мікроконтролерами, мережі безпровідних датчиків нового покоління 3 комп'ютерними чіпами, комплекс сучасних комп'ютерних систем 3 вбудованими контролерами для реалізації моніторингу, комутації і регулювання напруги та потоків потужності, комерційного обліку електроенергії, діагностики та електромагнітної сумісності включаючи системи захисту. В роботі [2] розглянуто архітектуру комп'ютерного середовища, що забезпечує інтелектуалізацію сукупності процедур оперативного диспетчерського i технологічного управління електропостачанням на тягу. Перший i, на нашу думку, базовий рівень архітектури комп'ютерного середовища представлений спеціалізованою локальною комп'ютерною мережею, при чому, в якості логічної структури якої може бути використана люба фізична топологія. Для управління швидкоплинними технологічними процесами електропостачання на рівні тягових підстанцій, в іiї локальній обчислювальній мережі, в якості вузлів використовується ряд комп'ютерних засобів для рішення широкого спектру розглянутих раніше задач i процедур ведення баз аварійних, комерційних і технологічних даних, а також формування первинної інформації у вигляді єдиного інформаційного середовища. Інші мережеві вузли локальної мережі тягової підстанції представляють ряд автономних мікропроцесорних систем для проведення безперервного моніторингу й ідентифікації режимів електричного обладнання та мереж електропостачання, визначення запасу ресурсу високовольтних вимикачів, моніторингу діелектричних параметрів силових трансформаторів, систем інтелектуального обліку електроенергії по комерційним тарифам, диференційованим за зонами доби, систем реєстрації первинної інформації. Тягові підстанції ЕЧЕ, що представляють нижній рівень єдиної системи постачання електроенергії на тягу кожної залізниці, можуть бути трьох типів - опорними, транзитними або тупиковими. Рівень тягових підстанцій, з точки зору електропостачання і відповідно організації первинних даних, що відображають весь комплекс параметрів режимів функціонування мереж електропостачання i силового обладнання, є домінуючим. Тому первинна інформація архівується і зберігається в необробленому вигляді, згідно нормативних документів відповідний термін, оскільки комерційні і аварійні дані в деяких випадках мають важливе юридичне значення. Таки чином, моделювання в реальному часі комплексу задач, які на рівні тягових підстанцій рішаються, в основному, в автоматичному режимі, може бути реалізовано на основі синтезу локальної комп'ютерної мережі спеціального призначення. Оскільки в процесі функціонування комп'ютерної мережі 3'являється необхідність проводити, в темпі електропостачання, обмін інформацією між вузлами локальної мережі і верхніми рівнями управління, а також проводити контроль достовірності, цілісності і конфіденційності, то топологія локальної мережі тягової підстанції, при необхідності, може змінюватися в процесі роботи в залежності від класу розв'язуваних задач в той чи інший проміжок часу, об'єму трафіку і стану системи електропостачання. В цьому плані широкі можливості при організації динаміки логічної структури локальної мережі тягової підстанції, без суттєвої зміни топології, представлять використання програмних комутаторів або магістральних маршрутизаторів. Інтелектуалізація процесу постачання електроенергії на рівні тягових підстанцій має бути реалізована в реальному часі електропостачання i високим рівнем надійності функціонування в зв'язку перевозкою пасажирів та вантажів, то в основу логічної структури спеціалізованої локальної мережі тягової підстанції будуть використані гармонійно зв'язані фізичні топології двох типів: фізична топологія «зірка» i «кільце». В якості мережних вузлів локальної мережі фізична топологія якої типу «кільце» використовуються мікропроцесорні системи для проведення моніторингу, ідентифікації режимів силового електричного обладнання, комерційного облік електроенергії та інші які виконують комплекс функцій управління роботою компонентів і сегментів мережі електропостачання. Завдяки фізичній топології «кільце» значно покращується надійність функціонування локальної мережі оскільки при виходу iз строю одного або декілька вузлів локальна мережа все рівно буде функціонувати. Процедури управління, на ріні тягової підстанції, обміном інформацією 3 вищими рівнями керуванням реалізуються завдяки створенню в локальній обчислювальній мережі комп'ютерного сегмента 3 фізичною топологією типу «зірка». В якості мережних вузлів їі використовується центральний сервер на який положено комплекс функцій управління роботою компонентів і сегментів мережі, сервер бази даних на базі якого реалізується формування єдиного інтегрованого середовища 
первинної інформації, а також декілька вузлів для моніторингу i управляння електропостачанням i обміну даними на всіх рівнях керування. Типова спеціалізована локальна мережа тягової підстанції, для проведення процедур інтелектуального управління постачанням електроенергії на тягу залізницям, представлена у вигляді графа на рис.1. В якості вузлів сегменту локальної мережі типу «зірка» використовується центральний сервер $S_{0}$ на який положено комплекс функцій управління роботою компонентів і сегментів мережі, а на сервер бази даних $S_{1}$ - формування єдиного інтегрованого середовища первинної інформації тягової підстанції включаючи ряд процедур ведення бази аварійних і комерційних даних, архівації, несанкціонованого доступу і захисту даних. В цей сегмент локальної мережі також входять два вузли $S_{2}$ і $S_{3}$ відповідно для організації обміну інформацією в рамках єдиної комп'ютерної мережі залізниці керування електропостачанням, а також передачі даних по Internet. Крім того, сегмент локальної мережі включає також вузол $S_{4}$, функціональні обов'язки якого систематично опитувати систему комерційного обліку електроенергії по тарифам диференційованим за зонами доби. Вузол $S_{5}$ представляє собою сервер диспетчерского центру 3 комплексом автоматизованих робочих місць оперативного управління електропостачанням на тягу. Сегмент логічної топології типу «коло» включає також вузли $S_{3}, S_{4}, S_{5}$, що входят в сегмент типу «зірка» $\mathrm{i}$ вузли: $S_{6}$ - опитування мікропроцесорних систем моніторингу силових тягових трансформаторів; $\mathrm{S}_{7}$ опитування мікропроцесорних систем моніторингу високовольтних вимикачів і засобів релейного захисту; $\mathrm{S}_{8}$ - опитування мікропроцесорних систем моніторингу параметрів режимів мереж електропостачання i силового обладнання. Дугами графа спеціалізованої локальної мережі тягової підстанції (рис. 1) представлена інтенсивність потоку заявок $\alpha(t)$ на обмін інформацією між компонентами локальної обчислювальної мережі тягової підстанції, і відповідно, інтенсивність $\beta(t)$ потоку обслуговування заявок $\alpha(t)$.

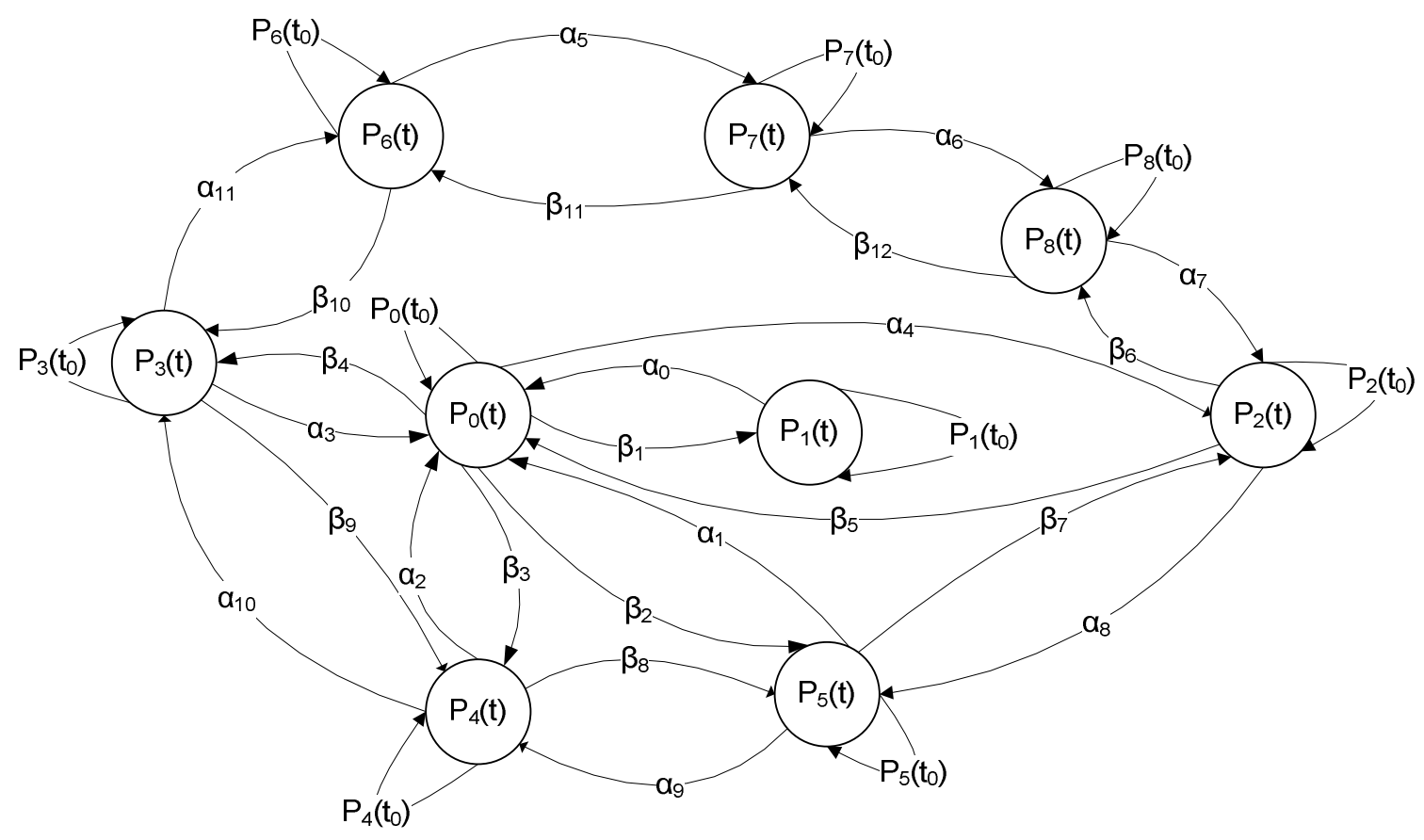

Рис. 1. Граф спеціалізованої локальної мережі тягової підстанції залізниці

Модель розглянутої на рис. 1 локальної мережі, як системи масового обслуговування, представлена у вигляді системи з очікуванням і обмеженою чергою. Потоки подій $\alpha(t), \quad \beta(t)$, що переводять систему із одного становища в інше згідно [5] можна віднести до класу пуасоновських. Для визначення сукупності характеристик системи таких як абсолютна пропускна здатність, середнє число заявок, середній термін чекання і ряд інших показників. Застосувавши правила i формули синтезуємо математичну модель представлену у вигляді рівнянь Колмогорова на основі яких можна визначити ймовірності $P_{0}(t), P_{l}(t), P_{2}(t)$, $P_{3}(t), P_{4}(t), P_{5}(t), P_{6}(t), P_{7}(t), P_{8}(t)$ стану відповідно вузлів $S_{0}, S_{1}, S_{2}, S_{3}, S_{4}, S_{5}, S_{6}, S_{7}, S_{8}$ графа локальної 
мережі тягової підстанції [5,8]. Сформована диференційних рівнянь 3 відповідними початковими математична модель представлена у вигляді системи умовами має вид

$\frac{d P_{0}}{d t}=\alpha_{0} P_{1}+\alpha_{1} P_{5}+\alpha_{2} P_{4}+\alpha_{3} P_{3}-\alpha_{4} P_{0}-\left(\beta_{1}+\beta_{2}+\beta_{3}+\beta_{4}\right) P_{0}-\beta_{5} P_{2}$

$\frac{d P_{1}}{d t}=-\alpha_{0} P_{1}+\beta_{1} P_{0}$

$\frac{d P_{2}}{d t}--\alpha_{8} \Gamma_{2}+4 \Gamma_{0}+\alpha_{7} 8+\beta_{7} 5+\beta_{5} P_{0}-\beta_{6} \Gamma_{8}$

$\frac{d P_{3}}{d t}=-\alpha_{11} P_{3}+\alpha_{3} P_{0}+\alpha_{10} P_{4}+\beta_{10} P_{6}+\beta_{4} P_{0}-\beta_{9} P_{3}$

$\frac{d F_{4}}{d t}=-\alpha_{2} P_{4}-\alpha_{10} P_{4}+\alpha_{9} P_{5}+\beta_{3} P_{0}-\beta_{8} P_{4}+\beta_{9} P_{3}$

$\frac{d P_{5}}{d t}=-\alpha_{1} P_{5}-\alpha_{9} P_{5}+\alpha_{8} P_{2}-\beta_{7} P_{5}+\beta_{2} P_{0}+\beta_{8} P_{4}$

$\frac{d P_{6}}{d t}=-\alpha_{5} P_{6}+\alpha_{11} P_{3}-\beta_{10} P_{6}+\beta_{11} P_{7}$

$\frac{d P_{7}}{d t}=-\alpha_{\epsilon} P_{7}+\alpha_{5} P_{6}-\beta_{11} P_{7}+\beta_{12} P_{\mathrm{R}}$

$\frac{d P_{8}}{d t}=-\alpha_{7} P_{\mathrm{g}}+\alpha_{6} P_{7}-\beta_{12} P_{\mathrm{g}}+\beta_{6} P_{2}$

Початкові умови для розв'язання системи (1) в момент $\mathrm{t}=0$ приймають значення $P_{0}(0)-1$, $P_{1}(0)-P_{2}(0)-\cdots-P_{\mathrm{g}}(0)-0, \quad$ що відповідає умовам нормування $P_{0}\left(t_{0}\right)+P_{1}\left(t_{0}\right)+\cdots+P_{8}\left(t_{0}\right)=1$.

Для рішення системи диференційних рівнянь (1) використаємо сучасні методи диференційних претворен Пухова [6], які представлені наступною парою математичних виразів у вигляді:

$X(k)=\frac{H^{k}}{K !}\left[\frac{d^{k} X(t)}{d t^{k}}\right]_{t=0} \quad x(t)=\sum_{k=0}^{k=\infty}\left(\frac{t}{H}\right)^{k} X(k)$,

де $x(t)$ - функція-оригінал, що представляє собою безперервну, нескінченне число раз диференціруєму функцію аргументу $t$, яка обмежена разом 3 усіма своїми похідними;

$X(K)$ - диференціальне зображення оригіналу $x(t)$, що представляє собою дискретну функцію цілочислового аргументу $H$ - масштабна постійна, що має ту ж розмірність що й аргумент $t$ і вибирається, як правило в діапазоні $0 \leq t \leq H$ на якому розглядається функція оригінал $\mathcal{X}(t)$;
- - символ відповідності між оригіналом $x(t)$ і диференціальним зображенням $X(K),(K=0,1,2, \ldots)$. У математичних залежностях (2) значення ліворуч від символу $\doteq$ називається пряме перетворення, що дозволяє по функції-оригіналу $x(t)$ одержати Тзображення $X(K)$, а праворуч - записане перетворення, що дозволяє за значенням дискрет $X(K), \quad K=0,1,2, \ldots$ одержати оригінал, що $x(t)$ представляється у формі степенного ряду. Необхідно відзначити, що отриманий оригінал $x(t) \epsilon$, по суті, ряд Тейлора в точці $t=0$

$X(k)=\frac{H^{k}}{k !}\left[\frac{d^{k} x(t)}{d t^{k}}\right]$

Застосувавши перетворення Пухова (2) для системи диференційних рівнянь (1) представимо математичну модель графа в області Т-зображень в наступному вигляді: 


$$
\begin{aligned}
P_{0}(k+1)= & \frac{H}{k+1}\left[\alpha_{0} P_{1}(k)+\alpha_{1} P_{5}(k)+\alpha_{2} P_{4}(k)+\alpha_{3} P_{3}(k)-\alpha_{4} P_{0}(k)\right. \\
& \left.-\left(\beta_{1}+\beta_{2}+\beta_{3}+\beta_{4}\right) P_{0}(k)-\beta_{5} P_{2}(k)\right] \\
P_{1}(k+1)= & \frac{H}{k+1}\left[\beta_{1} P_{0}(k)-\alpha_{0} P_{1}(k)\right] \\
P_{2}(k+1)= & \frac{H}{k+1}\left[\alpha_{4} P_{0}(k)+\alpha_{8} P_{2}(k)-\alpha_{8} P_{2}(k)-\beta_{5} P_{0}(k)-\beta_{6} P_{8}(k)\right] \\
P_{3}(k+1)= & \frac{H}{k+1}\left[\alpha_{3} P_{0}(k)+\alpha_{10} P_{4}(k)-\alpha_{11} P_{3}(k)+\beta_{10} P_{6}(k)+\beta_{4} P_{0}(k)\right. \\
& \left.-\beta_{6} P_{3}(k)\right] \\
P_{4}(k+1)= & \frac{H}{k+1}\left[\alpha_{9} P_{5}(k)-\alpha_{2} P_{4}(k)-\alpha_{10} P_{4}(k)+\beta_{3} P_{0}(k)-\beta_{8} P_{4}(k)+\right. \\
\left.+\beta_{9} P_{3}(k)\right] & \\
P_{5}(k+1)= & \frac{H}{k+1}\left[\alpha_{8} P_{2}(k)-\alpha_{1} P_{5}(k)-\alpha_{9} P_{5}(k)+\beta_{2} P_{0}(k)+\beta_{8} P_{4}(k)\right. \\
& \left.-\beta_{7} P_{5}(k)\right] \\
P_{6}(k+1)= & \frac{H}{k+1}\left[\alpha_{11} P_{3}(k)-\alpha_{5} P_{6}(k)+\beta_{11} P_{7}(k)-\beta_{10} P_{6}(k)\right] \\
P_{8}(k+1)= & \frac{H}{k+1}\left[\alpha_{6} P_{7}(k)-\alpha_{7} P_{8}(k)+\beta_{6} P_{2}(k)-\beta_{12} P_{8}(k)\right], k=1,2, \ldots \\
P_{7}(k+1)= & \frac{H}{k+1}\left[\alpha_{5} P_{6}(k)-\alpha_{6} P_{7}(k)+\beta_{12} P_{8}(k)-\beta_{11} P_{7}(k)\right] \\
\left.P_{0}\right) &
\end{aligned}
$$

Початкові умови на основі диференційних перетворень (2) можуть бути в Т-області представлені наступним чином:

$P_{0}(0)=P_{0}\left(t_{0}\right)=1, \quad P_{i}(0)=P_{i}\left(t_{0}\right)=0$, $i=1,2, \ldots, 8, \quad t_{0}=0$.

Система Т-рівнянь (4) являється основою для визначення значень ймовірностей $P_{0}(t), P_{l}(t), P_{2}(t)$, $P_{3}(t), P_{4}(t), P_{5}(t), P_{6}(t), P_{7}(t), P_{8}(t)$ стану вузлів графа, що відображає спеціалізовану локальну мережу тягової підстанції. Послідовно підставляючи значення цілочислового аргументу $k=0,1,2, \ldots$ в Т-модель (4) і обчислимо сукупність дискрет $P_{i}(k) i=0,1, . .8$, що, по суті i визначає рішення системи в Т-області. В подальшому реалізувавши підстановку отриманого спектру дискрет $P_{i}(k)$ в зворотне диференційне перетворення (2) получимо рішення - оригінал $P_{i}(t)$ дійсного аргументу $t$. Оскільки початкові умови в області Т-зображень відомі і представлені виразом (5), то підставив значення цілочислового аргументу $k=0$ в систему Т-рівнянь (4) отримаємо спектр дискрет $P_{i}(1)$ які приймуть значення

$$
P_{0}(1)=-H\left(\alpha_{4}+\beta_{1}+\beta_{2}+\beta_{3}+\beta_{4}\right)
$$

$P_{1}(1)=H \beta_{1}$

$P_{2}(1)=H\left(\alpha_{4}-\beta_{5}\right)$

$P_{3}(1)=H\left(\alpha_{3}+\beta_{4}\right)$

$P_{4}(1)=H \beta_{3}$

$$
P_{5}(1)=H \beta_{2}, P_{6}(1)=0, P_{7}(1)=0, \quad P_{8}(1)=0 .
$$

Для зручності введемо позначення $\alpha_{4}+\beta_{1}+\beta_{2}+$ $+\beta_{3}+\beta_{4}=\varphi$ і получимо значення $P_{0}(1)=-H \varphi$. Поступаючи по аналогії та підставив значення цілочислового аргументу $k=1$ в систему Т-рівнянь (5) визначимо сукупність Т- дискрет $P_{i}(2) \quad i=0,1, \ldots 8$, рішення в сфері зображень у вигляді 
$P_{0}(2)=\frac{H^{2}}{2}\left[\alpha_{0} \beta_{1}+\alpha_{1} \beta_{2}+\alpha_{2} \beta_{3}+\alpha_{3}\left(\alpha_{3}+\beta_{4}\right)+\varphi^{2}-\beta_{5}\left(\alpha_{4}-\beta_{5}\right)\right]$

$P_{1}(2)=\frac{H^{2}}{2} \beta_{1}\left(\varphi+\alpha_{0}\right)$

$P_{2}(2)=\frac{H^{2}}{2}\left[\left(\beta_{5}-\alpha_{4}\right) \varphi-\alpha_{8}\left(\alpha_{4}-\beta_{5}\right)-\beta_{2} \beta_{2}\right]$

$P_{3}(2)=\frac{H^{2}}{2}\left[\alpha_{10} \beta_{3}-\left(\alpha_{3}+\alpha_{4}\right) \varphi-\left(\alpha_{11}+\beta_{9}\right)\left(\alpha_{3}+\beta_{4}\right)\right]$

$P_{4}(2)=\frac{H^{2}}{2}\left[\alpha_{9} \beta_{2}-\left(\alpha_{2}+\alpha_{10}+\beta_{3}\right) \varphi+\beta_{9}\left(\alpha_{3}+\beta_{4}\right)\right]$,

$P_{5}(2)=\frac{H^{2}}{2}\left[\alpha_{3}\left(\alpha_{1}-\beta_{5}\right)\left(\alpha_{1}-\alpha_{9}\right) \beta_{2}-\left(\alpha_{10}+\beta_{8}+\varphi\right) \beta_{3}+\beta_{9}\left(\alpha_{3}+\beta_{4}\right)\right]$,

$P_{6}(2)=\frac{H^{2}}{2} \alpha_{11}\left(\alpha_{3}+\beta_{4}\right)$

$P_{7}(7)=0$

$P_{8}(2)=\frac{H^{2}}{2} \beta_{6}\left(\alpha_{4}+\beta_{5}\right)$

На основі отриманого Т-спектру $P_{0}(2), P_{1}(2)$, $P_{2}(2), P_{8}(2)$ значень функцій цілочислового аргументу $\mathrm{P}_{\mathrm{i}}(\mathrm{k})$ завдяки зворотним перетворенням (2) визначимо невідомі функції $P_{i}(t), \quad i=0,1, . .8$ аргументу $t$, що і $\epsilon$ рішення системи диференційних рівнянь (1), що в розгорнутому вигляді може бути записано як

$P_{i}(\mathrm{t})=\sum_{k=0}^{\infty}\left(\frac{t}{H}\right)^{k} P_{i}(k)=P_{i}(0)+\frac{t}{H} P_{i}(1)+\frac{t^{2}}{H^{2}} P_{i}(2)+\cdots$

Для визначення ймовірності стану $P_{0}(t)$ центрального сервера локальної обчислювальної мережі системи управління електропостачанням тягової підстанції підставимо в (8) значення Т- дискрет $F_{0}(0), P_{0}(1), F_{0}(2)$, отриманих згідно $(6),(7) \mathrm{i}$, в випадку $H=1$ отримаємо аналітичний вираз $P_{0}(t)$

$P_{0}(t)=1-\varphi t+\frac{1}{2}\left[\alpha_{0} \beta_{1}+\alpha_{1} \beta_{2}+\alpha_{2} \beta_{3}+\alpha_{3}\left(\alpha_{3}+\beta_{4}\right)+\varphi^{2}-\beta_{5}\left(\alpha_{4}-\beta_{5}\right)\right] t^{2}+$

По аналогії 3 вищенаведеному, сформуємо аналітичні залежності визначення ймовірностей

$P_{1}(t), P_{2}(t), P_{8}(t)$ стану інших вузлі локальної мережі

$$
\begin{aligned}
& P_{1}(t)=\beta_{1} t+\frac{1}{2} \beta_{1}\left(\varphi+\alpha_{0}\right) t^{2} \cdots \\
& P_{2}(t)=\left(\alpha_{4}-\beta_{5}\right) t+\frac{1}{2}\left[\left(\beta_{5}-\alpha_{4}\right) \varphi-\alpha_{8}\left(\alpha_{4}-\beta_{5}\right)-\beta_{7} \beta_{2}\right] t^{2}+\cdots \\
& P_{3}(t)=\left(\alpha_{3}-\beta_{4}\right) t+\frac{1}{2}\left[\alpha_{10} \beta_{3}-\left(\alpha_{3}+\beta_{4}\right) \varphi-\left(\alpha_{11}+\beta_{9}\right)\left(\alpha_{3}+\beta_{4}\right)\right] t^{2}+\cdots \\
& P_{8}(t)=\frac{1}{2} \beta_{6}\left(\alpha_{4}-\beta_{5}\right) t^{2} \cdots
\end{aligned}
$$

Отримані, в аналітичному виді, значення ймовірностей $P_{0}(t), P_{1}(t), P_{2}(t), P_{8}(t)$ станів вузлів локальної обчислювальної мережі тягової підстанції можуть взяті за основу обчислення іï характеристик. Підкреслимо, що 3 точки зору забезпечення надійності та безперебійності 
електропостачання на тягу, а також обміну інформацією 3 другими рівнями ієрархії системи управління електроспоживання, архітектура локальної обчислювальної мережі тягової підстанції синтезована, відповідним чином, на основі використання топології типу «кільце» куди входять вузли $S_{2}, S_{3}, S_{4}, S_{5}, S_{6}, S_{7}$, $S_{8}$ і типу «зірка», що включає вузли $S_{0}, S_{1}, S_{2}, S_{3}, S_{4}$, $S_{5}$. Завдяки такій організації архітектури обмін інформацією в середині локальної мережі між вузлами $S_{0}, S_{2}, S_{3}, S_{4}, S_{5}, S_{6}, S_{7}, S_{8}$ буде продовжуватися навіть при виході із ладу одного або декілька вузлів. Обмін даними між іншими сегментами системи управління електропостачанням такими як спеціалізовані локальні обчислювальні мережі дистанцій електропостачанні або корпоративної обчислювальної мережі окремої залізниці реалізується за допомогою центрального серверу $S_{0}$ через вузол $S_{2}$ в рамках єдиної комп'ютерної мережі залізниці керування електропостачанням, а також через вузол $S_{3}$, що забезпечує окрему передачу даних по Internet. В зв'язку 3 цим, розглянемо методи визначення характеристик локальної обчислювальної мережі тягової підстанції з точки зору загрузки іiі в процесі обміну інформацією на основі ймовірностей $P_{0}(t)$ $P_{1}(t), P_{2}(t), P_{8}(t)$ станів вузлів які можуть бути визначені згідно (9). Оскільки на центральний сервер $S_{0}$ постійно поступає потік інтенсивності заявок $\alpha_{0}(t)$, $\alpha_{1}(t), \quad \alpha_{2}(t), \quad \alpha_{3}(t)$ на обмін даними, то завдяки архітектурній організації локальної обчислювальної мережі, як говорилося раніш, ймовірність того, що вони будуть прийняті і обслужені, буде відповідно $P_{0}(t)$ згідно (9). У випадку, коли одна або декілька заявок потоків інтенсивності $\alpha_{0}(t), \alpha_{1}(t), \alpha_{2}(t), \alpha_{3}(t)$ отримають відмову, то ймовірність відмови $q(t) \epsilon$ доповнення $P_{0}(t)$ до одиниці, тобто

$$
\begin{aligned}
& q(t)=1-P_{0}(t)= \\
& =\varphi t-\frac{1}{2}\left[\alpha_{0} \beta_{1}+\alpha_{1} \beta_{2}+\alpha_{2} \beta_{3}+\alpha_{3}\left(\alpha_{3}+\beta_{4}\right)+\varphi^{2}-\beta^{5}\left(\alpha_{4}-\beta_{3}\right)\right] t^{2} .
\end{aligned}
$$

Абсолютна пропускна спроможність $A(t)$ через вузол $S_{2}$ в рамках єдиної комп’ютерної мережі локальної обчислювальної мережі тягової підстанції залізниці може бути представлена виразом

$$
\begin{aligned}
& A(t)=\alpha_{m} q(t)= \\
& =\varphi \alpha_{m} t-\frac{\alpha_{m}}{2}\left[\alpha_{0} \beta_{1}+\alpha_{1} \beta_{2}+\alpha_{2} \beta_{3}+\alpha_{3}\left(\alpha_{3}+\beta_{4}\right)+\varphi^{2}-\beta_{5}\left(\alpha_{4}-\beta_{5}\right)\right] t^{2} \\
& \alpha_{m}=\max _{i}\left\{\alpha_{i(t)}\right\} \cdot i=0,1,2,3 .
\end{aligned}
$$

Дуже важливою характеристикою також $\epsilon$ величина, що характеризує середнє число зайнятих каналів $\Theta(t)$, що може бути записано в вигляді

$$
\begin{aligned}
& \theta(t)=\frac{A(t)}{\beta_{m}}=\frac{\alpha_{m}\left[1-P_{0}(t)\right]}{\beta_{m}}, \\
& \beta_{m}=\operatorname{midx}_{j}\left\{\beta_{i}(c)\right\}, \quad j=1,2,3,4 \\
& q_{2}(t)=1-P_{2}(t)=1-\left(\alpha_{4}-\beta_{5}\right) t+\frac{1}{2}\left[\left(\beta_{5}-\alpha_{4}\right) \varphi-\alpha_{8}\left(\alpha_{4}-\beta_{5}\right)-\beta_{7} \beta_{2}\right] t^{2} \\
& A_{2}(t)=\alpha_{2 m} q_{2}(t)=\alpha_{2 m}-\left(\alpha_{4}-\beta_{5}\right) \alpha_{2 m} t+\frac{1}{2}\left[\left(\beta_{5}-\alpha_{4}\right) \varphi-\alpha_{8}\left(\alpha_{4}-\beta_{5}\right)-\right. \\
& \left.-\beta_{2} \beta_{2}\right\rfloor t^{2} \\
& \theta_{2}(t)=\frac{A_{2}(t)}{\beta_{2 m}}=\frac{\alpha_{2 m}}{\beta_{2 m}}\left\lceil 1-P_{2}(t)\right\rceil
\end{aligned}
$$

Аналогічно вищепредставленому, можна отримати рід інших характеристик локальної обчислювальної мережі тягової підстанції, наприклад для вузла $\mathrm{S}_{2}$, на який покладено ряд функцій пов'язаних 3 обміном інформацією 3 різними комп'ютерними сегменти єдиної комп'ютерної мережі залізниці. При цьому, сукупність математичних залежностей для визначення характеристик, згідно (9)-(13) мають вигляд 
І Н Ф О Р М А Ц І Й Н О - К Е Р У Ю Ч І С И С Т Е М И Н А З А Л І З Н И Ч Н О М У Т Р А Н С П О Р Т І

Поступивши згідно запропонованого підходу визначення ймовірностей станів $P_{0}(t), P_{1}(t), P_{2}(t)$, $\ldots, P_{8}(t)$, а також обчислення значень характеристик локальної обчислювальної мережі можна реалізувати синтез з заданими параметрами комп'ютерних компонентів мережі і інтелектуальну систему управління електропостачання залізниці.

\section{Висновки \\ 1. На основі проведеного аналізу комплексної проблеми оптимізації режимів електропостачання на тягу, енергозбереження, забезпечення безпеки руху i еволюції розвитку електричних мереж залізниць можна заключить, що загальновизнаним у світі, в цьому плані, став напрямок пов'язаний 3 інтелектуалізацією тягових електричних мереж, що базується на SMART Grid - технології. Цей факт стимулював проведення наукових досліджень в сфері створення нових концептуальних підходів, принципів інтелектуалізації режимів функціонування тягових систем, математичних моделей та методів комп'ютеризації швидкоплинних технологічних процесів електроспоживання i на їх базі способів організації інтелектуальних електричних мереж залізниць.}

2. На основі дослідження спільних властивостей математичних моделей, методів, алгоритмів, задач управління електричними мережами, особливостей сучасних комп'ютерних засобів та базуючись на принципі єдиного інформаційного простору 3 метою інтелектуалізації процедур електроспоживання запропоновано топологію графа, що адекватно відображає архітектуру типової локальної обчислювальної мережі тягової підстанції, в якому гармонійно пов'язані фізичні топології «зірка» i «кільце», що відкриває можливість реалізувати синтез математичних моделей і методів оптимізації електроспоживання, досліджувати глибину взаємоінтеграції електромережевої інфраструктури та інформаційної комп'ютерної архітектури, організації всережимної системи керування та розширення ринкових можливостей, а також формування процедур культури споживання та стимулювання економічного розвитку.

3. Запропонована математична модель у вигляді системи диференційних рівнянь Колмогорова 3 відповідними початковими умовами для визначення сукупності ймовірностей стану відповідно вузлів графа і характеристик локальної мережі тягової підстанції для оцінки можливості повномасштабного інформаційного забезпечення інтелектуальних електричних мереж залізниць та реалізації сучасних IT- технології енергозбереження i безпеки руху залізничного транспорту.
4. Розроблена, на основі сучасного математичного апарату диференційних перетворень Пухова, математична модель представлена в області Т-зображень завдяки чому відкривається можливість достатньо просто отримати в аналітичному вигляді значення ймовірностей станів вузлів локальної обчислювальної мережі тягової підстанції та визначити ряд характеристик мережі таких як ймовірність відмови заявок на обслуговування, абсолютна пропускна спроможність, середнє число зайнятих каналів, що $\epsilon$ основою створення інтелектуальних мереж постачання електроенергії на тягу залізницям.

\section{Література}

1. Стогній Б.С. Еволюція інтелектуальних електричних мереж та їхні перспективи н в Україні // Стогній Б.С., Кириленко О.В., Праховник А.В., Денисюк С.П. ; Технічна електродинаміка 2012, №5 - С. 52-66.

2. Стасюк О.І. Методи організації інтелектуальних електричних мереж залізниць на основі концепції SMART Grid// Гончарова Л.Л., Максимчук В.Ф. Інформаційно-керуючі системи на залізничному транспорті, науково-технічний журнал, Харків 2014, № 2 -С.29-37.

3. Стогний Б.С. Методы организации компьютерных систем коммерческого управления электрическими объектами. //Стогний Б.С., Сопель М.Ф., Стасюк А.И., Стасюк И.А Зб. наукових праць. Моделювання та інформаційні технології./ Випуск 15, НАН України. Інститут проблем моделювання в енергетиці ім. Г.С. Пухова. Київ - 2002.- С.3-15.

4. Гончарова Л.Л. Информационные технологии мониторинга режимов электрических сетей на основе дифференциальных Т-моделей. / Гончарова Л.Л. // Інформаційно-керуючі системи на залізничному транспорті, науково-технічний журнал, Харків - 2009, № 4 - С. 93-97.

5. Венцель Е.С. Исследование операцій.// Венцель Е.С.; Москва «Сов.радио» 1972 г. С 551.

6. Пухов Г.Е. Преобразовании Тейлора и их применение в электротехнике и электронике.// Пухов Г.Е.; Киев «Наукова думска» 1978 г. С.259.

7. Стасюк O.I. Підвищення надійності моніторингу допустимості завантажень контрольованих перетинів енергосистем // Стасюк O.I., Буткевич О.Ф., ЛевконюкА.В. Технічна електродинаміка, Київ - 2014, №2 - С.56-67.

8. Стасюк O.I. Методи комп'ютерної інтелектуалізації режимів функціонування тягових мереж залізниць// Стасюк O.I., Гончарова Л.Л., Максимчук В.Ф., Голуб Г.М., Інформаційнокеруючі системи на залізничному транспорті, науково-технічний журнал, Харків - 2013, № 5 C. $29-35$. 
9. Стасюк О.I. Методи синтезу розподілених комп'ютерно-інтегрованих мереж і технологій інтелектуалізації, моніторингу та оптимізації режимів електропостачання i енергозбереження залізниць// Стасюк O.I., Гончарова Л.Л., Максимчук В.Ф., Інформаційно-керуючі системи на залізничному транспорті, науково-технічний журнал, Харків - 2015, № 1 -С.3-10.

Стасюк А.И., Гончарова Л.Л. Математические модели и методы организации интеллектуальных сетей поставки электроэнергии на тягу железнодорожному транспорту. Проведён комплексный анализ проблемы оптимизации режимов электроснабжения на тягу, предложено топологию графа адекватно отображающего архитектуру типовой локальной вычислительной сети тяговой подстанции и математическую модель для определения набору вероятностей соответствующих узлов, применен математический аппарат дифференциальных преобразований Пухова, как основа создания интеллектуальных сетей поставок электроэнергии и определения их характеристик.

Ключові слова: Интеллектуальные электрические сети, математические модели, SMART Grid, дифференциальные преобразования, локальная сеть, тяговая подстанция.
Stasiuk A.I., Goncharova L.L. Mathematical models and methods of organization of intelligent networks to supply electricity for railway transport traction. Comprehensive analysis of the problem of optimization of the modes to supply electricity for traction has been performed. The topology of the graph adequately displaying the architecture of a typical local computer network of a traction substation and a mathematical model to determine a set of probabilities of corresponding nodes has been proposed. Pukhov's mathematical apparatus of differential transformations as the basis for the development of intellectual networks for electricity supply, and for the determination of their characteristics has been applied.

Key words: intellectual electric networks, mathematical models, SMART Grid, differential transformations, LAN, traction substation.

Рецензент д.т.н., професор Тимченко Л.I. (ДЕТУТ)

Поступила 13.02.20152.

Stasiuk O. I. Doctor of engineering, professor, head of department "Automation and Computer-Integrated Technologies of Transport" State Economic and Technological University of Transport, laureate of the State Prize of Ukraine, Kyiv, Ukraine.

Goncharova L. L., Ph.D., Assistant professor of "Automation and Computer-Integrated Technologies of Transport" State Economic and Technological University of Transport, Kyiv, Ukraine. 